\title{
Haemagglutination with Plant and Insect Viruses
}

\author{
By J. C. CUNNINGHAM AND T. W. TINSLEY \\ Insect Pathology Unit, Department of Forestry, University of Oxford \\ AND J. M. WALKER \\ Department of Pharmacology, University of Oxford
}

(Received 14 September 1965)

\begin{abstract}
SUMMARY
The passive haemagglutination test and the sensitivity of the haemagglutination inhibition test were investigated by using two plant viruses (tobacco mosaic virus and latent carnation virus) and an insect virus, tipula iridescent virus. The minimum quantities detectable by these methods were of the order of 0.26 to $0.015 \mu \mathrm{g}$. There was no direct agglutination by tobacco mosaic virus or tipula iridescent virus of erythrocytes from a variety of animals.
\end{abstract}

\section{INTRODUCTION}

The passive haemagglutination test (HA) with tanned erythrocytes and the related haemagglutination-inhibition test (HI) can be used to detect very small quantities of antibody and antigen. These tests are based on the technique of Boyden (1951) who found that the treatment of sheep erythrocytes with suitable concentrations of tannic acid rendered them capable of adsorbing a variety of proteins. The advantages, limitations, sensitivity and specificity of these methods have been discussed and illustrated experimentally by Stavitsky (1954). The passive haemagglutination technique has been widely used in medical virology (Friedman \& Bennett, 1957; Scott, Felton \& Barney, 1957; Benedict \& O'Brien, 1958; McKenna, Zuschek \& Frankel, 1958; Garabedian, 1965). Matthews (1957) suggested that this technique might have applications in plant virology. Passive haemagglutination with six plant viruses was shown by Saito \& Iwata (1964). Their results showed that the haemagglutination titre was 100 to 40,000 times higher than the complementfixation titre. They described three methods for detecting virus by the haemagglutination-inhibition test including a technique in which the $\gamma_{2}$ globulin fraction of the antiserum was purified and used to sensitize the tanned erythrocytes which were then agglutinated in the presence of homologous virus. The smallest quantity of virus detected was reported to be $10^{-8} \mathrm{~g}$. Haemagglutination inhibition (HI) has been used with insect viruses to detect free virus particles in the haemocoele (MacGregor, 1956). Although the HA test is of potential value in plant and insect virology, the HI test is likely to prove a more useful technique and its sensitivity was thought worthy of investigation.

Direct haemagglutination of erythrocytes from a variety of species has been reported for several animal viruses and it provides a simple and rapid means of virus assay. There are no reports of direct haemagglutination with plant or insect 
viruses, so erythrocytes of some common laboratory animals were tested with plant and insect viruses. The viruses used were tobacco mosaic virus (TMV), latent carnation virus (LCV) and tipula iridescent virus (TIV).

\section{METHODS}

Purification of virus. Highly purified preparations of virus are required in haemagglutination techniques to decrease non-specific reactions. TMV was purified by two ammonium sulphate precipitations, followed by two cycles of high- and low-speed centrifugation.

Latent carnation virus and its homologous antiserum were kindly supplied by Mr M. Hollings, Glasshouse Crops Research Institute, Rustington, Sussex.

TIV was purified by cycles of high- and low-speed centrifugation and finally in a sucrose gradient.

Preparation of antisera. Rabbits were immunized with TMV and TIV by a total of six intravenous injections, each containing $3 \mathrm{mg}$. virus and given at 3-day intervals. The rabbits were bled 10 days after the last injection and the sera preserved by the addition of equal volumes of glycerol and stored at $4^{\circ}$.

Passive haemagglutination. Rabbits were bled from the ear and the blood collected in Alsever's solution. The red cells were washed thrice in normal saline and after the third washing $1 \mathrm{ml}$. packed red cells was diluted in $40 \mathrm{ml}$. phosphatebuffered saline ( $\mathrm{pH} \mathbf{7 \cdot 2}$ ). Three volumes of diluted red cells were incubated with three volumes of $1 / 25,000$ tannic acid (Analar) at $37^{\circ}$ for $10 \mathrm{~min}$. The tanned red cells were then washed with 3 vol. of phosphate buffer ( $\mathrm{pH} \mathrm{7 \cdot 2)}$ and finally resuspended in 2 vol. of normal saline $(0.85 \%, w / v, \mathrm{NaCl})$.

In sensitizing the tanned red cells, two factors had to be considered: (1) the optimal $\mathrm{pH}$ value for the reaction; (2) the optimal concentration of antigen/ml. tanned red cells. A series of tests was arranged for each antigen, phosphate + citrate

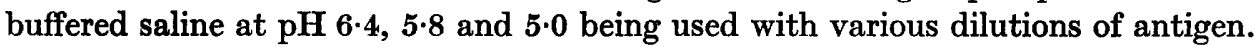
$\mathrm{pH} 5 \cdot 0$ was found to be the optimal value for all the viruses. Spontaneous agglutination occurred when too much virus was added to the tanned red cells.

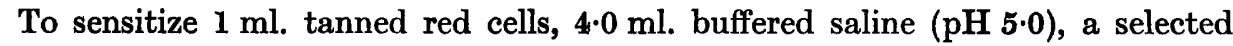
concentration of antigen in $0.5 \mathrm{ml}$. saline and $1 \mathrm{ml}$. tanned red cells in saline were added to a tube in that order and incubated for $20 \mathrm{~min}$. at room temperature. The red cells were sedimented by low-speed centrifugation (100g) and washed in $1.5 \mathrm{ml}$. of $1 / 100$ normal rabbit serum diluted in $0.8 \%$ saline. The sensitized red cells were finally resuspended in $1.5 \mathrm{ml}$. 1/100 normal rabbit serum.

Control red cells were prepared by adding $0.5 \mathrm{ml}$. saline to $4.0 \mathrm{ml}$. buffer (pH 5.0) followed by $1 \mathrm{ml}$. tanned red cells and then treated like the sensitized cells.

Titration of antiserum. Serial 2-fold dilutions of antiserum were made in $9 \times 75$ $\mathrm{mm}$. tubes using $0.2 \mathrm{ml}$. antiserum and $0.2 \mathrm{ml}$. 1/100 normal rabbit serum; $0.2 \mathrm{ml}$. normal rabbit serum was added to each tube, bringing the total volume to $0.4 \mathrm{ml}$. Samples $(0.05 \mathrm{ml}$.) of sensitized red cells were added to each tube in the titration, $0.05 \mathrm{ml}$. of control cells were added to a tube containing the highest concentration of antiserum, and the tubes were kept at room temperature. Readings were taken after $3 \mathrm{hr}$ and again after $12 \mathrm{hr}$; the results were interpreted by using the standards suggested by Stavitsky (1954). 
Haemagglutination inhibition test. Serial 2-fold dilutions of antigen $(0.2 \mathrm{ml}$.) of known concentration in $1 / 100$ normal rabbit serum were made in $0 \cdot 2 \mathrm{ml}$. of $1 / 100$ normal rabbit serum. The highest dilution of antiserum which gave marked haemagglutination was chosen for $\mathrm{HI}$ tests and $\mathbf{0} \cdot \mathbf{2} \mathrm{ml}$. of this diluted antiserum was added to each tube. Controls consisting of antiserum $+1 / 100$ normal rabbit serum, virus $+1 / 100$ normal rabbit serum and 1/100 normal rabbit serum alone were arranged and all the tubes incubated at $37^{\circ}$ for $3 \mathrm{hr} ; 0.05 \mathrm{ml}$. of sensitized red cells were then added to each tube and readings taken after 3 and $12 \mathrm{hr}$. The last tube which showed no haemagglutination or only doubtful haemagglutination was taken as the end-point of the titration.

Direct haemagglutination. Perspex plates containing 80 small wells were washed before use in the sequence of $2 \%$ caustic soda, tap water, $5 \% \mathrm{HCl}$, tap water and thrice in distilled water. Red cells were collected in Alsever solution and washed thrice with normal saline. A range of $\mathrm{pH}$ values from 4.2 to $8 \cdot 0$, in steps of $0.2 \mathrm{pH}$ unit, was used. Phosphate + citrate buffers were used from $\mathrm{pH} 4 \cdot 2$ to $6 \cdot 0$ and phosphate buffers from $\mathrm{pH} \mathrm{6.2} \mathrm{to} 8 \cdot 0.0 \cdot 5 \mathrm{ml}$. of each buffer was added to two rows of wells in each plate. $0 \cdot 1 \mathrm{mg}$. virus in saline was added to the first row and saline alone to the second as a control. On the third washing the red cells of the species being tested were centrifuged at $500 \mathrm{~g}$ for $5 \mathrm{~min}$. One $\mathrm{ml}$. of packed red cells was added to $100 \mathrm{ml}$. of saline containing $\mathbf{0 . 2} \%$ bovine $\gamma$-globulin to prevent non-specific haemagglutination; $\mathbf{0 . 5} \mathrm{ml}$. of diluted red cells were added to each well. The results were clearly visible in $1 \mathrm{hr}$.

Table 1. Haemagglutination by antisera to tipula iridescent virus (TIV), tobacco mosaic virus (TMV) and latent carnation virus (LCV)

\begin{tabular}{lcccccc}
\multicolumn{5}{c}{ Reciprocal of dilution of antiserum } \\
\cline { 2 - 5 } Virus & $\mathbf{1 , 0 0 0}$ & $\mathbf{2 , 0 0 0}$ & $\mathbf{4 , 0 0 0}$ & $\mathbf{8 , 0 0 0}$ & $\mathbf{1 6 , 0 0 0}$ & $\mathbf{3 2 , 0 0 0}$ \\
TIV & ++++ & ++++ & ++++ & ++++ & ++++ & ++ \\
TMV & ++++ & ++++ & ++++ & ++++ & ++++ & ++++ \\
LCV & ++++ & +++ & ++++ & ++++ & ++++ & ++++ \\
& $\mathbf{6 4 , 0 0 0}$ & $\mathbf{1 2 8 , 0 0 0}$ & $\mathbf{2 5 6 , 0 0 0}$ & $\mathbf{5 1 2 , 0 0 0}$ & $\mathbf{1 , 0 2 4 , 0 0 0}$ & $\mathbf{2 , 0 4 8 , 0 0 0}$ \\
TIV & \pm & \pm & - & - & - & - \\
TMV & ++ & + & \pm & - & - & - \\
LCV & ++++ & +++ & +++ & ++ & \pm & -
\end{tabular}

RESULTS

\section{Passive haemagglutination}

All the antisera were found to have very high $\mathrm{HA}$ titres and the dilutions were started at $1 / 1000$. The antisera were diluted with 1/100 normal rabbit serum. In all tests controls of red cells sensitized with saline instead of antigen, and antiserum replaced by 1/100 normal rabbit serum, were used and no haemagglutination was observed.

The optimal quantities of virus necessary to sensitize $1 \mathrm{ml}$. red cells were found to be: TIV $0.3 \mathrm{mg}$. virus; TMV $0.23 \mathrm{mg}$.; LCV $0.05 \mathrm{mg}$. These quantities did not necessarily give the highest titre when reacted with their homologous antisera but they did give marked haemagglutination to a dilution very near the end-point.

The results of the HA titrations are given in Table 1. The TIV antiserum gave a titre of $1 / 32,000$, the TMV $1 / 128,000$ and the LCV $1 / 512,000$. 


\section{Haemagglutination inhibition}

The sensitivity of the HI test was considerably increased by the selection of the highest dilution of antiserum which caused agglutination. The antisera dilutions selected were those which gave the last strong $\mathrm{HA}$ reaction $(++++$ or +++$)$ in the HA titration and were: TIV 1/16,000; TMV 1/30,000; LCV 1/250,000.

The quantity of virus in the first tube was arbitrarily selected and serial 2-fold dilutions made. The results of the test are shown in Table 2. The minimum quantity of virus detected by HI was found to be: $0.26 \mu \mathrm{g}$. for TIV; $0.015 \mu \mathrm{g}$. for TMV; 0.024 $\mu \mathrm{g}$. for LCV.

\section{Direct haemagglutination}

TMV did not agglutinate fowl, rabbit, rat, mouse, hamster, human or sheep erythrocytes in a range $\mathrm{pH} 4.2$ to $\mathrm{pH} 8.0$ at room temperature. Considerable lysis was noted below $\mathrm{pH} \mathrm{5.0.} \mathrm{TMV} \mathrm{and} \mathrm{TIV} \mathrm{did} \mathrm{not} \mathrm{agglutinate} \mathrm{goose} \mathrm{erythrocytes}$ between pH 4.2 and 8.0 at $37^{\circ}$ or $4^{\circ}$.

Table 2. Dilution end points of tobacco mosaic virus (TMV), tipula iridescent virus (TIV) and latent carnation virus (LCV) determined by the haemagglutination-inhibition test

\begin{tabular}{|c|c|c|c|c|c|c|c|c|c|c|c|}
\hline \multirow[b]{2}{*}{ Virus } & \multirow{2}{*}{$\begin{array}{l}\text { Mg. } \\
\text { virus } \\
\text { in } \\
\text { first } \\
\text { tube }\end{array}$} & \multicolumn{10}{|c|}{ Serial double dilutions of virus } \\
\hline & & 1 & 2 & 3 & 4 & 5 & 6 & 7 & 8 & $\mathbf{9}$ & 10 \\
\hline $\begin{array}{l}\text { TIV } \\
\text { TMV }\end{array}$ & $\begin{array}{l}0.00012 \\
0.00175 \\
0.00089\end{array}$ & $=$ & $=$ & $\begin{array}{l}- \\
-\end{array}$ & \pm & $\begin{array}{c}+++ \\
-\end{array}$ & $\begin{array}{c}++ \\
++\end{array}$ & $+t+$ & $+t+$ & $\begin{array}{c}++ \\
++\end{array}$ & $\begin{array}{l}+++ \\
++++\end{array}$ \\
\hline & 0.00089 & - & - & - & - & \pm & +++ & +++ & +++ & +++ & ++++ \\
\hline
\end{tabular}

The haemagglutination inhibition (HI) test is more sensitive for the detection of virus in plant and insect pathology than any existing method. The selection of an antiserum dilution very close to the end-point of the haemagglutination (HA) titration greatly enhanced the sensitivity of the reaction. The results of HA tests were subject to variation but this was decreased by using fresh blood in each experiment and an antiserum dilution near the end-point can be used with confidence.

The minimum quantities of virus detected were of the same order as those reported by Saito \& Iwata (1964) who used sensitization of tanned erythrocytes with $\gamma_{2}$ globulin. The two rod-shaped plant viruses were detectable in slightly lower concentration than was the spherical insect virus.

Attempts to obtain direct haemagglutination of tobacco mosaic virus failed, though it is possible that erythrocytes from other animals than those tested and at wider $\mathrm{pH}$ ranges might yield positive results.

Since the HI test is capable of detecting very small quantities of virus it might be useful in a study of the early stages of virus synthesis. It would be particularly valuable with insect viruses as the only method of assay is by LD50 tests which are both time-consuming and equivocal.

J. C. Cunningham was in receipt of an Agricultural Research Council postgraduate studentship during the period of study. 


\section{REFERENCES}

Benedict, A. A. \& O'Brien, E. (1958). A passive haemagglutination reaction for psittacosis. J. Immunol. 80, 94.

BoYDEN, S. V. (1951). The adsorption of proteins on erythrocytes treated with tannic acid and subsequent haemagglutination by anti-protein sera. J. exp. Med. 93, 107.

Friedman, M. \& BennetT, C. R. (1957). A haemagglutination test for detection of adenovirus antibodies. Proc. Soc. exp. Biol. Med. 94, 712.

Garabedian, G. A. (1965). The behaviour of tanned erythrocytes in various haemagglutination systems. J. gen. Microbiol. 38, 181.

MacGregor, D. R. (1956). Unpublished data quoted by G. H. Bergold, in Insect Pathology (1963) vol I. London and New York: Academic Press.

McKenna, J. M., Zuschek, F. \& Frankel, J. W. (1958). A haemagglutination test for titration of antibodies to polioviruses. Proc. Soc. exp. Biol. Med. 97, 160.

Matthews, R. E. F. (1957). Plant Virus Serology, p. 116. Cambridge University Press.

SaIto, Y. \& IwaTa, Y. (1964). Haemagglutination test for titration of plant virus. Virology, 22, 426.

Scotr, L. V., Felton, F. G. \& Barney, J. A. (1957). Haemagglutination with herpes simplex virus. J. Immunol. 78, 211.

Stavitsky, A. B. (1954). Micromethods for the study of proteins and antibodies. I. Procedure and general applications of haemagglutination inhibition reactions with tannic acid and protein-treated red blood cells. J. Immunol. 72, 360. 